\title{
PKM PERANGKAT DESA BLONGKO KECAMATAN SINONSAYANG KABUPATEN MINAHASA SELATAN
}

\author{
Kristofel Santa \\ Fakultas Teknik Universitas Negeri Manado \\ Email : kristofelsanta@unima.ac.id
}

\begin{abstract}
ABSTRAK
Desa Blongko merupakan desa yang berada dalam Kecamatan Sinonsayang Kabupaten Minahasa Selatan Provinsi Sulawesi Utara. Pada tahun 1985 Desa Blongko resmi menjadi desa definitive dimana sistem pemerintahan desa berkedudukan di Blongko. Sebelum tahun 1985 perkampungan ini masih desa persiapan untuk menjadi desa definitive, dahulunya adalah berstatus jaga/dusun jauh dari desa Boyong Pante. Pemerintah desa blongko merupakan Mitra yang tidak produktif secara ekonomi karena merupakan organisasi yang bergerak di bidang pelayanan kepada masyarakat. Pemerintah desa blongko mengatur dan mengurus kebutuhan masyarakat desa yang berjumlah jumlah 1.685 Orang, yang tersebar pada luas 1.000 hektar luas wilayah desa. Berdasarkan kesepakatan dengan Mitra yaitu pemerintah desa blongko kecamatan sinonsayang kabupaten minahasa selatan, permasalahan yang akan diselesaikan tahun 2019 yaitu: Lambatnya penyelesaian surat menyurat; Kurangnya pengetahuan tentang Aplikasi Microsoft Office Word dalam surat menyurat; Kurangnya pengetahuan tentang Aplikasi Microsoft Office Excel dalam surat menyurat serta penyusunan anggaran desa; Kurangnya pengetahuan dari perangkat desa tentang penerapan teknologi informasi dalam penyelenggaraan pemerintahan desa khususnya bidang administrasi. Beberapa solusi yang ditawarkan dalam menyelesaikan permasalahan yang dihadapi oleh desa mitra antara lain: meningkatkan keterampilan perangkat desa dalam penyelesaian surat menyurat, meningkatkan pengetahuan perangkat desa tentang aplikasi Microsoft Word dalam surat menyurat, meningkatkan pengetahuan perangkat desa tentang aplikasi Microsoft Excel dalam surat menyurat serta penyusunan anggaran desa, meningkatkan pengetahuan perangkat desa tentang penerapan teknologi informasi dalam penyelenggaraan pemerintahan desa dengan layanan prima. Luaran yang akan dihasilkan dari masing-masing solusi atas permasalahan yang dihadapi mitra ada 2 luaran yaitu Jasa dan Produk. Setiap program kegiatan yang telah dilaksanakan akan dilakukan evaluasi secara berkelanjutan melalui Hukum Tua Desa Blongko Kecamatan Sinonsayang Kabupaten Minahasa Selatan.
\end{abstract}

Kata Kunci: Perangkat Desa; Teknologi Informasi Blongko 


\section{PENDAHULUAN}

Dewasa ini, pintu untuk dilakukannya inovasi di pemerintah desa semakin terbuka lebar dengan dikeluarkannya Undang-Undang Nomor 23 Tahun 2014 tentang Pemerintah Daerah dan kemudian sebagian materinya diubah dengan Perpu Nomor 2 Tahun 2014. Didalam Undang-Undang Nomor 23 Tahun 2014 disebutkan bahwa dalam rangka peningkatan kinerja penyelenggaraan pemerintah daerah, Pemerintah Daerah dapat melakukan inovasi. Inovasi adalah semua bentuk pembaharuan dalam penyelenggaraan pemerintahan desa. Oleh karena itu, dapat disimpulkan bahwa inovasi diperlukan pemerintah desa sebagai langkah yang strategis dalam perbaikan penyelenggaraan pemerintahan desa yang baik dan bersih.

Desa Blongko merupakan salah satu pemerintah daerah yang perlu melakukan inovasi dibidang kinerja pelayanan dan meningkatkan daya saing daerah. Hal tersebut disebabkan karena jarak dari ibukota kabupaten $32 \mathrm{KM}$ dan Jarak dari Ibukota Provinsi $115 \mathrm{KM}$, yang memungkinkan terlambatnya informasi yang dibutuhkan pemerintah desa. Tingkat pendidikan perangkat desa bervariasi dari tamatan SD sampai dengan Sarjana, dijelaskan pada table berikut:

Tabel 1. Tingkat Pendidikan Perangkat Desa Blongko

\begin{tabular}{|l|l|c|r|}
\hline No & Tingkat Pendidikan & Jumlah & Persentase (\%) \\
\hline 1 & Tamatan SD & 6 & 37.50 \\
\hline 2 & Tamatan SMP & 1 & 6.25 \\
\hline 3 & Tamatan SMA & 7 & 43.75 \\
\hline 4 & Tamatan Sarjana & 1 & 6.25 \\
\hline
\end{tabular}

Berdasarkan Tabel 1. Untuk tingkat pendidikan tamatan SD memiliki 6 orang perangkat desa dengan prosentase 37.50 , untuk tingkatan Tamatan SMA memiliki 7 orang perangkat desa dengan prosentase 43.75 sedangkan untuk Tamatan SMP dan Tamatan Sarjana hanya memiliki 1 orang perangkat desa dengan prosentase 6.25 , sebaran umur perangkat desa terlihat pada tabel berikut:

Tabel 2. Sebaran Umur Perangkat Desa Blongko

\begin{tabular}{|l|l|c|r|}
\hline No & Umur (Tahun) & Jumlah & Persentase (\%) \\
\hline 1 & $<40$ & 10 & 62.50 \\
\hline 2 & $41-50$ & 4 & 25.00 \\
\hline 3 & $>50$ & 2 & 12.50 \\
\hline
\end{tabular}

Berdasarkan Tabel 2. Untuk sebaran umur kurang dari 40 Tahun memiliki 10 orang perangkat desa dengan prosentase 62.50, untuk sebaran umur dengan rentang umur 41 tahun sampai dengan umur 50 tahun memiliki 4 orang perangkat desa, untuk sebaran umur lebih dari 50 tahun memiliki 2 orang perangkat desa.

Berdasarkan sebaran umur dan tingkatan pendidikan dari perangkat desa blongko, maka dapat disimpulkan bahwa perangkat desa mampu menyerap materi berupa teknologi informasi yang dapat mereka wujudkan melalui inovasi dalam menyelesaikan masalah layanan administrasi kependudukan, keuangan, pertanahan, perpajakan perlu dilakukan inovasi terhadap output yang akan dihasilkan yaitu bentuk pelayanan prima (cepat, tepat dan akurat).

Berdasarkan kesepakatan dengan Mitra yaitu pemerintah desa blongko kecamatan sinonsayang kabupaten minahasa selatan, permasalahan yang akan diselesaikan tahun 2019 yaitu:

1) Lambatnya penyelesaian surat menyurat.

2) Kurangnya pengetahuan tentang Aplikasi Microsoft Office Word dalam surat menyurat.

3) Kurangnya pengetahuan tentang Aplikasi Microsoft Office Excel dalam surat menyurat serta penyusunan anggaran desa.

4) Kurangnya pengetahuan dari perangkat desa tentang penerapan teknologi informasi dalam penyelenggaraan pemerintahan desa khususnya bidang administrasi.

5) Kurangnya ketersediaan peralatan teknologi informasi di kantor desa.

\section{SOLUSI PERMASALAHAN}

Solusi yang ditawarkan untuk menyelesaikan permasalahan yang dihadapi mitra secara sistematis sesuai dengan prioritas permasalahan.

Tabel 3. Solusi Permasalahan

\begin{tabular}{|l|l|l|}
\hline No & \multicolumn{1}{|c|}{ Pemasalahan } & \multicolumn{1}{c|}{ Solusi } \\
\hline 1 & $\begin{array}{l}\text { Lambatnya } \\
\text { penyelesaian surat } \\
\text { menyurat. }\end{array}$ & $\begin{array}{l}\text { Meningkatkan } \\
\text { keterampilan } \\
\text { perangkat desa dalam } \\
\text { penyelesaian surat } \\
\text { menyurat. }\end{array}$ \\
\hline 2 & $\begin{array}{l}\text { Kurangnya } \\
\text { pengetahuan } \\
\text { tentang Aplikasi } \\
\text { Microsoft Office } \\
\text { Word dalam surat } \\
\text { menyurat. }\end{array}$ & $\begin{array}{l}\text { Meningkatkan } \\
\text { pengetahuan } \\
\text { perangkat desa } \\
\text { tentang aplikasi } \\
\text { Microsoft Word } \\
\text { dalam surat } \\
\text { menyurat. }\end{array}$ \\
\hline 3 & $\begin{array}{l}\text { Kurangnya } \\
\text { pengetahuan } \\
\text { tentang Aplikasi } \\
\text { Microsoft Office } \\
\text { Excel dalam surat }\end{array}$ & $\begin{array}{l}\text { Meningkatkan } \\
\text { pengetahuan } \\
\text { perangkat desa } \\
\text { tentang aplikasi } \\
\text { Microsoft Excel }\end{array}$ \\
\hline
\end{tabular}




\begin{tabular}{|c|c|c|}
\hline & $\begin{array}{l}\text { menyurat serta } \\
\text { penyusunan } \\
\text { anggaran desa. }\end{array}$ & $\begin{array}{l}\text { dalam surat menyurat } \\
\text { serta penyusunan } \\
\text { anggaran desa. }\end{array}$ \\
\hline 4 & $\begin{array}{l}\text { Kurangnya } \\
\text { pengetahuan dari } \\
\text { perangkat desa } \\
\text { tentang penerapan } \\
\text { teknologi informasi } \\
\text { dalam } \\
\text { penyelenggaraan } \\
\text { pemerintahan desa } \\
\text { dengan layanan } \\
\text { prima. }\end{array}$ & $\begin{array}{l}\text { Meningkatkan } \\
\text { pengetahuan } \\
\text { perangkat desa } \\
\text { tentang penerapan } \\
\text { teknologi informasi } \\
\text { dalam } \\
\text { penyelenggaraan } \\
\text { pemerintahan desa } \\
\text { dengan layanan } \\
\text { prima. }\end{array}$ \\
\hline 5 & $\begin{array}{l}\text { Kurangnya } \\
\text { ketersediaan } \\
\text { peralatan teknologi } \\
\text { informasi di kantor } \\
\text { desa. }\end{array}$ & $\begin{array}{l}\text { Memberikan } \\
\text { Peralatan teknologi } \\
\text { informasi di kantor } \\
\text { desa }\end{array}$ \\
\hline
\end{tabular}

Tabel 4. Solusi Permasalahan

\begin{tabular}{|c|c|c|}
\hline No & Solusi & Program Kegiatan \\
\hline \multirow[t]{2}{*}{1} & \multirow{2}{*}{$\begin{array}{l}\text { Meningkatkan } \\
\text { keterampilan } \\
\text { perangkat desa } \\
\text { dalam } \\
\text { penyelesaian } \\
\text { surat menyurat. }\end{array}$} & $\begin{array}{l}\text { Pemberian Materi } \\
\text { tentang surat menyurat }\end{array}$ \\
\hline & & $\begin{array}{l}\text { Pengenalan Software } \\
\text { untuk surat menyurat }\end{array}$ \\
\hline \multirow[t]{5}{*}{2} & \multirow{5}{*}{$\begin{array}{l}\text { Meningkatkan } \\
\text { pengetahuan } \\
\text { perangkat desa } \\
\text { tentang aplikasi } \\
\text { Microsoft Word } \\
\text { dalam surat } \\
\text { menyurat. }\end{array}$} & $\begin{array}{l}\text { Pengenalan Materi } \\
\text { penggunaan Microsoft } \\
\text { Office Word }\end{array}$ \\
\hline & & Pengenalan Materi \\
\hline & & $\begin{array}{l}\text { Fungsi Aplikasi } \\
\text { Microsoft Office Word }\end{array}$ \\
\hline & & $\begin{array}{l}\text { Prosedur memperoleh } \\
\text { Aplikasi Microsoft } \\
\text { Office Word }\end{array}$ \\
\hline & & $\begin{array}{l}\text { Instalasi Aplikasi } \\
\text { Microsoft Office }\end{array}$ \\
\hline \multirow[t]{6}{*}{3} & \multirow{6}{*}{$\begin{array}{l}\text { Meningkatkan } \\
\text { pengetahuan } \\
\text { perangkat desa } \\
\text { tentang aplikasi } \\
\text { Microsoft Excel } \\
\text { dalam surat } \\
\text { menyurat serta } \\
\text { penyusunan } \\
\text { anggaran desa. }\end{array}$} & $\begin{array}{l}\text { Pengenalan Materi } \\
\text { penggunaan Microsoft } \\
\text { Office Excel }\end{array}$ \\
\hline & & Pengenalan Materi \\
\hline & & Fungsi Aplikasi \\
\hline & & $\begin{array}{l}\text { Microsoft Office Excel } \\
\text { Prosedur memneroleh }\end{array}$ \\
\hline & & $\begin{array}{l}\text { Aplikasi Microsoft } \\
\text { Office Excel }\end{array}$ \\
\hline & & $\begin{array}{l}\text { Instalasi Aplikasi } \\
\text { Microsoft Office }\end{array}$ \\
\hline \multirow[t]{3}{*}{4} & \multirow{3}{*}{$\begin{array}{l}\text { Meningkatkan } \\
\text { pengetahuan } \\
\text { perangkat desa } \\
\text { tentang } \\
\text { penerapan } \\
\text { teknologi } \\
\text { informasi dalam } \\
\text { penyelenggaraan } \\
\text { pemerintahan }\end{array}$} & $\begin{array}{l}\text { Pemberian materi } \\
\text { tentang Mail-Merge } \\
\text { File (Koneksi Word } \\
\text { dan Excel) }\end{array}$ \\
\hline & & $\begin{array}{l}\text { Pemberian materi } \\
\text { tentang Database } \\
\text { sederhana }\end{array}$ \\
\hline & & $\begin{array}{l}\text { Pemberian materi } \\
\text { tentang E-Bussiness } \\
\text { (Layanan Prima) }\end{array}$ \\
\hline
\end{tabular}

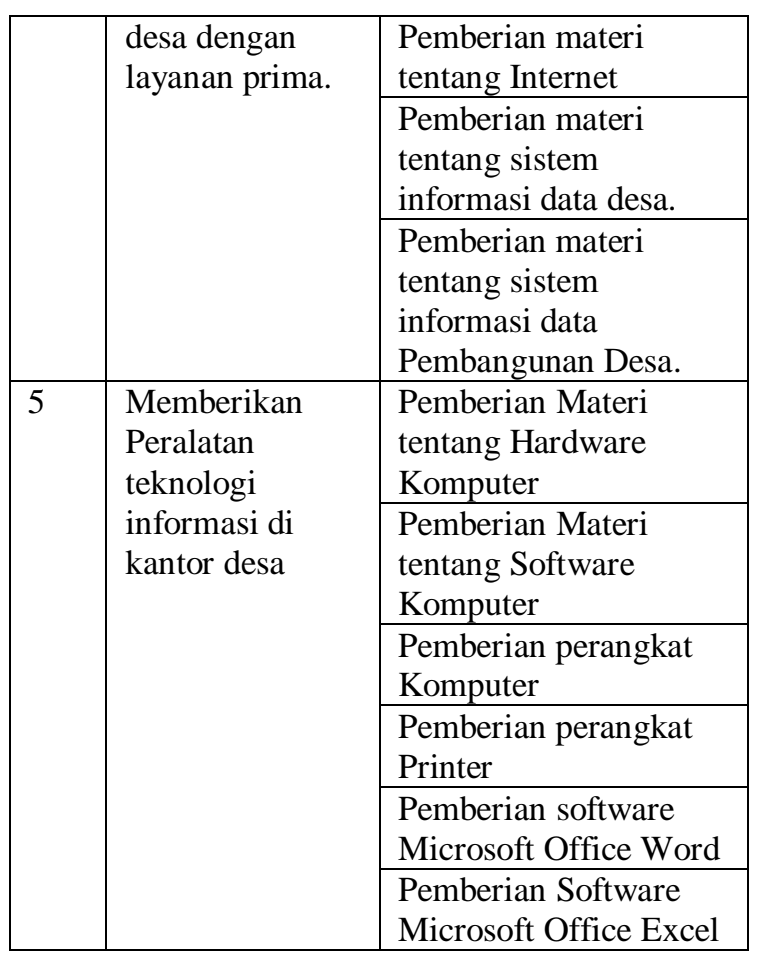

Jenis luaran yang akan dihasilkan dari masing-masing solusi atas permasalahan yang dihadapi mitra dari kelompok masyarakat yang tidak produktif secara ekonomi / sosial.

Tabel 5. Luaran yang akan dicapai dari setiap solusi

\begin{tabular}{|l|l|l|}
\hline No & Jenis Luaran & $\begin{array}{l}\text { Indikator } \\
\text { Pencapaian }\end{array}$ \\
\hline $\begin{array}{l}\text { Luaran Yang Akan Dicapai Terhadap } \\
\text { Permasalahan Ke-1 }\end{array}$ \\
\hline 1 & $\begin{array}{l}\text { Pemberian Materi } \\
\text { tentang surat menyurat }\end{array}$ & Jasa \\
\hline 2 & $\begin{array}{l}\text { Pengenalan Software } \\
\text { untuk surat menyurat }\end{array}$ & Jasa dan Produk \\
\hline $\begin{array}{l}\text { Luaran Yang Akan Dicapai Terhadap } \\
\text { Permasalahan Ke-2 }\end{array}$ & $\begin{array}{l}\text { Pengenalan Materi } \\
\text { Office Word }\end{array}$ & Jasa \\
\hline 1 & $\begin{array}{l}\text { Pengenalan Materi } \\
\text { Fungsi Aplikasi } \\
\text { Microsoft Office Word }\end{array}$ & Jasa \\
\hline 3 & $\begin{array}{l}\text { Prosedur memperoleh } \\
\text { Aplikasi Microsoft } \\
\text { Office Word }\end{array}$ & Jasa \\
\hline 4 & $\begin{array}{l}\text { Instalasi Aplikasi } \\
\text { Microsoft Office }\end{array}$ & $\begin{array}{l}\text { Jasa dan Produk } \\
\text { Fungsi Aplikasi } \\
\text { Muarosoft Office Excel } \\
\text { Permasalahan Ke-3 }\end{array}$ \\
\hline 1 & $\begin{array}{l}\text { Pengenalan Materi } \\
\text { Office Excel }\end{array}$ & Jasa \\
\hline 2 & \begin{tabular}{l} 
Pengenalan Materi \\
\hline
\end{tabular} & Jasa \\
\hline
\end{tabular}




\begin{tabular}{|l|l|l|}
\hline 3 & $\begin{array}{l}\text { Prosedur memperoleh } \\
\text { Aplikasi Microsoft } \\
\text { Office Excel }\end{array}$ & Jasa \\
\hline 4 & $\begin{array}{l}\text { Instalasi Aplikasi } \\
\text { Microsoft Office }\end{array}$ & Jasa dan Produk \\
\hline $\begin{array}{l}\text { Luaran Yang Akan Dicapai Terhadap } \\
\text { Permasalahan Ke-4 }\end{array}$ & $\begin{array}{l}\text { Pemberian materi } \\
\text { tentang Mail-Merge File } \\
\text { (Koneksi Word dan } \\
\text { Excel) }\end{array}$ & Jasa dan Produk \\
\hline 2 & $\begin{array}{l}\text { Pemberian materi } \\
\text { tentang Database } \\
\text { sederhana }\end{array}$ & Jasa \\
\hline 3 & $\begin{array}{l}\text { Pemberian materi } \\
\text { tentang E-Bussiness } \\
\text { (Layanan Prima) }\end{array}$ & Jasa \\
\hline 4 & $\begin{array}{l}\text { Pemberian materi } \\
\text { tentang Internet }\end{array}$ & Jasa \\
\hline 5 & $\begin{array}{l}\text { Pemberian materi } \\
\text { tentang sistem informasi } \\
\text { data desa. }\end{array}$ & Jasa \\
\hline 6 & $\begin{array}{l}\text { Pemberian materi } \\
\text { tentang sistem informasi } \\
\text { data Pembangunan } \\
\text { Desa. }\end{array}$ & Jasa \\
\hline $\begin{array}{l}\text { Luaran Yang Akan Dicapai Terhadap } \\
\text { Permasalahan Ke-5 }\end{array}$ & $\begin{array}{l}\text { Pemberian Materi } \\
\text { tentang Hardware } \\
\text { Komputer }\end{array}$ & Jasa \\
\hline 2 & $\begin{array}{l}\text { Pemberian Materi } \\
\text { tentang Software } \\
\text { Komputer }\end{array}$ & Jasa \\
\hline 3 & $\begin{array}{l}\text { Pemberian perangkat } \\
\text { Komputer }\end{array}$ & Produk \\
\hline 4 & $\begin{array}{l}\text { Pemberian perangkat } \\
\text { Printer }\end{array}$ & Produk \\
\hline 5 & $\begin{array}{l}\text { Pemberian software } \\
\text { Microsoft Office Word }\end{array}$ & Produk \\
\hline 6 & $\begin{array}{l}\text { Pemberian Software } \\
\text { Microsoft Office Excel }\end{array}$ & Produk \\
\hline
\end{tabular}

\section{METODE PELAKSANAAN}

Langkah-langkah yang ditempuh guna melaksanakan solusi atas permasalahan spesifik yang dihadapi oleh mitra.

Tabel 6. Metode Penyelesaian Masalah

\begin{tabular}{|c|c|c|}
\hline No & $\begin{array}{c}\text { Program Kegiatan } \\
\text { menyelesaikan } \\
\text { masalah }\end{array}$ & $\begin{array}{c}\text { Metode } \\
\text { Penyelesaian } \\
\text { Masalah }\end{array}$ \\
\hline 1 & $\begin{array}{lr}\text { Pemberian } & \text { Materi } \\
\text { tentang } & \text { surat } \\
\text { menyurat } & \end{array}$ & $\begin{array}{ll}- & \text { Penyuluhan } \\
\text { - } & \text { Ceramah } \\
& \text { menggunakan } \\
& \text { audio visual }\end{array}$ \\
\hline
\end{tabular}

\begin{tabular}{|c|c|c|}
\hline 2 & $\begin{array}{l}\text { Pengenalan } \\
\text { Software untuk } \\
\text { surat menyurat }\end{array}$ & $\begin{array}{ll}- & \text { Penyuluhan } \\
- & \text { Ceramah } \\
& \text { menggunakan } \\
& \text { audio visual } \\
- & \text { Pelatihan } \\
\end{array}$ \\
\hline 3 & $\begin{array}{l}\text { Pengenalan Materi } \\
\text { penggunaan } \\
\text { Microsoft Office } \\
\text { Word }\end{array}$ & $\begin{array}{ll}- & \text { Penyuluhan } \\
- & \text { Ceramah } \\
& \text { menggunakan } \\
& \text { audio visual }\end{array}$ \\
\hline 4 & $\begin{array}{l}\text { Pengenalan Materi } \\
\text { Fungsi Aplikasi } \\
\text { Microsoft Office } \\
\text { Word }\end{array}$ & $\begin{array}{ll}- & \text { Penyuluhan } \\
- & \text { Ceramah } \\
& \text { menggunakan } \\
& \text { audio visual }\end{array}$ \\
\hline 5 & $\begin{array}{l}\text { Prosedur } \\
\text { memperoleh } \\
\text { Aplikasi Microsoft } \\
\text { Office Word }\end{array}$ & $\begin{array}{ll}- & \text { Penyuluhan } \\
- & \text { Ceramah } \\
& \text { menggunakan } \\
& \text { audio visual } \\
-\quad & \text { Pelatihan }\end{array}$ \\
\hline 6 & $\begin{array}{l}\text { Instalasi Aplikasi } \\
\text { Microsoft Office }\end{array}$ & $\begin{array}{ll}- & \text { Penyuluhan } \\
- & \text { Ceramah } \\
& \text { menggunakan } \\
& \text { audio visual } \\
- & \text { Pelatihan } \\
\end{array}$ \\
\hline 7 & $\begin{array}{l}\text { Pengenalan Materi } \\
\text { penggunaan } \\
\text { Microsoft Office } \\
\text { Excel } \\
\end{array}$ & $\begin{array}{ll}- & \text { Penyuluhan } \\
\text { - } & \text { Ceramah } \\
& \text { menggunakan } \\
& \text { audio visual } \\
\end{array}$ \\
\hline 8 & $\begin{array}{l}\text { Pengenalan Materi } \\
\text { Fungsi Aplikasi } \\
\text { Microsoft Office } \\
\text { Excel } \\
\end{array}$ & $\begin{array}{ll}- & \text { Penyuluhan } \\
- & \text { Ceramah } \\
& \text { menggunakan } \\
& \text { audio visual } \\
\end{array}$ \\
\hline 9 & $\begin{array}{l}\text { Prosedur } \\
\text { memperoleh } \\
\text { Aplikasi Microsoft } \\
\text { Office Excel }\end{array}$ & $\begin{array}{ll}- & \text { Penyuluhan } \\
- & \text { Ceramah } \\
& \text { menggunakan } \\
& \text { audio visual } \\
- & \text { Pelatihan } \\
\end{array}$ \\
\hline 10 & $\begin{array}{l}\text { Instalasi Aplikasi } \\
\text { Microsoft Office }\end{array}$ & $\begin{array}{ll}- & \text { Penyuluhan } \\
- & \text { Ceramah } \\
& \text { menggunakan } \\
& \text { audio visual } \\
- & \text { Pelatihan }\end{array}$ \\
\hline 11 & $\begin{array}{l}\text { Pemberian materi } \\
\text { tentang Mail-Merge } \\
\text { File (Koneksi Word } \\
\text { dan Excel) }\end{array}$ & $\begin{array}{ll}- & \text { Penyuluhan } \\
- & \text { Ceramah } \\
& \text { menggunakan } \\
& \text { audio visual } \\
- & \text { Pelatihan }\end{array}$ \\
\hline 12 & $\begin{array}{l}\text { Pemberian materi } \\
\text { tentang Database } \\
\text { sederhana }\end{array}$ & $\begin{array}{ll}- & \text { Penyuluhan } \\
- & \text { Ceramah } \\
& \text { menggunakan } \\
& \text { audio visual } \\
\end{array}$ \\
\hline 13 & $\begin{array}{l}\text { Pemberian materi } \\
\text { tentang E-Bussiness } \\
\text { (Layanan Prima) }\end{array}$ & $\begin{array}{ll}- & \text { Penyuluhan } \\
- & \text { Ceramah } \\
& \text { menggunakan } \\
& \text { audio visual } \\
\end{array}$ \\
\hline 14 & $\begin{array}{l}\text { Pemberian materi } \\
\text { tentang Internet }\end{array}$ & $\begin{array}{ll}- & \text { Penyuluhan } \\
- & \text { Ceramah } \\
& \text { menggunakan } \\
& \text { audio visual } \\
- & \text { Pelatihan }\end{array}$ \\
\hline
\end{tabular}




\begin{tabular}{|c|c|c|}
\hline 15 & $\begin{array}{l}\text { Pemberian materi } \\
\text { tentang sistem } \\
\text { informasi data desa. }\end{array}$ & $\begin{array}{ll}\text { - } & \text { Penyuluhan } \\
\text { - } & \text { Ceramah } \\
\text { menggunakan } \\
\text { audio visual }\end{array}$ \\
\hline 16 & $\begin{array}{l}\text { Pemberian materi } \\
\text { tentang sistem } \\
\text { informasi data } \\
\text { Pembangunan Desa. }\end{array}$ & $\begin{array}{ll}- & \text { Penyuluhan } \\
\text { - } & \text { Ceramah } \\
\text { menggunakan } \\
\text { audio visual } \\
\end{array}$ \\
\hline 17 & $\begin{array}{l}\text { Pemberian Materi } \\
\text { tentang Hardware } \\
\text { Komputer }\end{array}$ & $\begin{array}{ll}- & \text { Penyuluhan } \\
\text { - } & \text { Ceramah } \\
& \text { menggunakan } \\
& \text { audio visual } \\
- & \text { Pelatihan }\end{array}$ \\
\hline 18 & $\begin{array}{l}\text { Pemberian Materi } \\
\text { tentang Software } \\
\text { Komputer }\end{array}$ & $\begin{array}{ll}- & \text { Penyuluhan } \\
\text { - } & \text { Ceramah } \\
\text { menggunakan } \\
\text { audio visual } \\
\text { - } & \text { Pelatihan }\end{array}$ \\
\hline 19 & $\begin{array}{l}\text { Pemberian } \\
\text { perangkat Komputer }\end{array}$ & $\begin{array}{ll}\text { - } & \text { Ceramah } \\
\text { menggunakan } \\
\text { audio visual } \\
\text { - } & \text { Pelatihan } \\
\end{array}$ \\
\hline 20 & $\begin{array}{l}\text { Pemberian } \\
\text { perangkat Printer }\end{array}$ & $\begin{array}{ll}\text { - } & \text { Ceramah } \\
\text { menggunakan } \\
\text { audio visual } \\
-\quad \text { Pelatihan } \\
\end{array}$ \\
\hline 21 & $\begin{array}{l}\text { Pemberian software } \\
\text { Microsoft Office } \\
\text { Word }\end{array}$ & $\begin{array}{ll}\text { - } & \text { Ceramah } \\
\text { menggunakan } \\
\text { audio visual } \\
\text { - } & \text { Pelatihan }\end{array}$ \\
\hline 22 & $\begin{array}{l}\text { Pemberian Software } \\
\text { Microsoft Office } \\
\text { Excel }\end{array}$ & $\begin{array}{ll}\text { - } & \text { Ceramah } \\
\text { menggunakan } \\
\text { audio visual } \\
\text { - } & \text { Pelatihan } \\
\end{array}$ \\
\hline
\end{tabular}

Partisipasi dari pemerintah desa blongko sebagai mitra yaitu:

1. Pemerintah desa blongko kecamatan sinonsayang kabupaten minahasa selatan akan menyiapkan tempat penyuluhan dan pelatihan.

2. Seluruh perangkat desa blongko ikut serta mengikuti penyuluhan dan pelatihan.

3. Seluruh perangkat desa blongko merespon dengan baik materi penyuluhan dan pelatihan.

4. Seluruh perangkat desa blongko terlibat aktif dalam praktek penyuluhan dan pelatihan.

Evaluasi pelaksanaan program setelah kegiatan PKM selesai dilaksanakan

Evaluasi adalah rangkaian kegiatan membandingkan realisasi masukan (input), keluaran (output), dan hasil (outcome) terhadap rencana dan standar. Evaluasi merupakan merupakan kegiatan yang menilai hasil yang diperoleh selama kegiatan pemantauan berlangsung. Lebih dari itu, evaluasi juga menilai hasil atau produk yang telah dihasilkan dari suatu rangkaian program sebagai dasar mengambil keputusan tentang tingkat keberhasilan yang telah dicapai dan tindakan selanjutnya yang diperlukan. Evaluasi pelaksanaan program setelah kegiatan PKM selesai, dilakukan dengan cara:

- Setiap program kegiatan yang telah dilaksanakan diberikan angket untuk diisi oleh seluruh peserta yang mengikuti program kegiatan.

- Setelah pelaksanaan PKM, penanda tanganan Pakta Integritas untuk menjamin semua yang sudah disampaikan/dilatihankan dapat dilakukan secara terus-menerus untuk menjaga penyelenggaraan pemerintahan desa dengan layanan prima.

- Pemantauan secara berkelanjutan melalui Hukum Tua Desa Blongko Kecamatan Sinonsayang Kabupaten Minahasa Selatan.

Pendampingan terus menerus untuk setiap perangkat desa sehingga kegiatan ini berjalan secara terus menerus.

\section{HASIL DAN PEMBAHASAN}

Yang menjadi hasil dan luaran dari pengabdian kepada masyarakat Desa Bongko Kecamatan Sinonsayang Kabupaten Minahasa Selatan ini adalah

Tabel 7. Hasil dan Luaran

\begin{tabular}{|l|l|l|}
\hline No & \multicolumn{1}{|c|}{ Pemasalahan } & Hasil dan luaran \\
\hline 1 & $\begin{array}{l}\text { Lambatnya } \\
\text { penyelesaian surat } \\
\text { menyurat. }\end{array}$ & $\begin{array}{l}\text { Tersedianya } \\
\text { Aplikasi Surat- } \\
\text { menyurat }\end{array}$ \\
\hline 2 & $\begin{array}{l}\text { Kurangnya } \\
\text { pengetahuan tentang } \\
\text { Aplikasi Microsoft } \\
\text { Office Word dalam } \\
\text { surat menyurat. }\end{array}$ & $\begin{array}{l}\text { Peningkatan } \\
\text { pengetahuan dan } \\
\text { ketrampilan bagi } \\
\text { perangkat desa dan } \\
\text { masyarakat desa } \\
\text { Blongko tentang } \\
\text { Aplikasi Microsoft } \\
\text { Office Word }\end{array}$ \\
\hline 3 & $\begin{array}{l}\text { Kurangnya } \\
\text { pengetahuan tentang } \\
\text { Aplikasi Microsoft } \\
\text { Office Excel dalam } \\
\text { surat menyurat serta } \\
\text { penyusunan } \\
\text { anggaran desa. }\end{array}$ & $\begin{array}{l}\text { Peningkatan } \\
\text { pengetahuan dan } \\
\text { ketrampilan bagi } \\
\text { perangkat desa dan } \\
\text { masyarakat desa } \\
\text { Blongko tentang } \\
\text { Aplikasi Microsoft } \\
\text { Office Excel }\end{array}$ \\
\hline 4 & $\begin{array}{l}\text { Kurangnya } \\
\text { pengetahuan dari } \\
\text { perangkat desa } \\
\text { tentang penerapan } \\
\text { teknologi informasi } \\
\text { dalam }\end{array}$ & $\begin{array}{l}\text { Peningkatan } \\
\text { pengetahuan bagi } \\
\text { perangkat desa dan } \\
\text { masyarakat desa } \\
\text { Blongko tentang } \\
\text { Penerapan }\end{array}$ \\
\hline
\end{tabular}




\begin{tabular}{|l|l|l|}
\hline & $\begin{array}{l}\text { penyelenggaraan } \\
\text { pemerintahan desa } \\
\text { dengan layanan } \\
\text { prima. }\end{array}$ & $\begin{array}{l}\text { Teknologi } \\
\text { Informasi dalam } \\
\text { penyelenggaraan } \\
\text { pemerintahan desa. }\end{array}$ \\
\hline 5 & $\begin{array}{l}\text { Kurangnya } \\
\text { ketersediaan } \\
\text { peralatan teknologi } \\
\text { informasi di kantor } \\
\text { desa. }\end{array}$ & $\begin{array}{l}\text { Tersedianya } \\
\text { peralatan teknologi } \\
\text { informasi di kantor } \\
\text { desa Blongko }\end{array}$ \\
\hline
\end{tabular}

\section{KESIMPULAN}

Berdasarkan hasil pelaksanaan kegiatan yang telah dilakukan, dapat ditarik beberapa simpulan sebagai berikut;

a. Pembuatan aplikasi surat-menyurat dan tersedianya peralatan teknologi informasi di kantor desa Blongko dapat membantu terlaksananya pelayanan yang prima kepada masyarakat desa blongko kecamatan sinonsayang kabupaten minahasa selatan

b. Penyampaian pengetahuan tentang pemanfaatan aplikasi Microsoft Word dan Excel dapat meningkatkan pengetahuan bagi perangkat desa blongko.

c. Penyampaian pengetahuan tentang penerapan teknologi informasi dalam penyelenggaraan pemerintahan desa dapat membantu perangkat desa mewujudkan pelayanan yang prima kepada masyarakat.

\section{REFERENSI}

BPS, 2013. Kecamatan Sinonsayang dalam Angka. BPS Propinsi Sulawesi Utara. Manado

Muluk, Khairul. 2008. Knowledge Management; Kunci Sukses Inovasi Pemerintahan Daerah. Malang: Bayu Media.

Asropi. 2008. "Budaya Inovasi dan Reformasi Birokrasi“. Jurnal Ilmu Administrasi, Vol. V, No. 3, September 2008. 